\title{
Indigenous Asian Specialty Vegetables in the Central Valley of California
}

\author{
Richard H. Molinar ${ }^{1}$ \\ University of California Cooperative Extension, 1720 S Maple Avenue, Fresno, CA 93702
}

Additional index words. luffa, sinqua, bittermelon, moqua, yardlong beans, opo, lemongrass, Asian, Oriental vegetables, specialty

\begin{abstract}
Sinqua and moqua, better known as Luffa actuangula and Benincasa hispida var. chiehgua, are but a few of the 70 or so Asian vegetables being grown in Fresno, CA. These little-known vegetables are very common to the $1300 \mathrm{Hmong}$, Mien, Lao, and Chinese farmers growing them for the specialty and wholesale markets in Fresno. This article discusses 24 Asian vegetables commonly grown on farms and sold to more than a dozen specialty crop packing houses in Fresno and at farmers markets in California. Cultural information, pest problems, and culinary uses are also briefly discussed.
\end{abstract}

\section{THE STATE AND VALLEY}

California has been the number one agricultural state for over 50 years. More than $85 \%$ of California's farms are classified as family farms or partnerships and more than $60 \%$ of the state's farms consist of 50 acres or less (California Agriculture, 2003; California Farm, 2003; USDA-NASS, 2002). The Central Valley of California stretches from Shasta County to Kern County. The area is $\approx 430$ miles long and 75 miles wide and includes 18 of the 58 counties in California and $1 \%$ of the U.S farmland (Great Valley, 1999). It is considered the most productive region in the state and nation, producing over $50 \%$ of the nation's fruits and vegetables.

\section{THE CROPS}

California produces over 400 different kinds of crops. It is, without doubt, the most diversified in the world with no one crop dominating. The very high numbers of Asian farmers in the state account for the significant acreage of Asian specialty crops being grown in California and the Central Valley (Tables 1-2).

\section{THE PEOPLE}

The ethnic diversity of this state and the various counties directly contribute to the crop diversity and agriculture production in California. Southeast Asian farmers in Fresno include Hmong, Mien, Lao, Chinese, Japanese, Khmu, Lahu, Filipino, and others. A high proportion of Asian farmers are refugees who came to the United States. during the period 1976-2005 as a result of persecution after the Vietnam War. The Asian vegetable farmers in Fresno are comprised primarily of Hmong from the mountain regions of Laos (62\%) and ethnic Lao from the Laotian lowlands (30\%) (Ilic, 1992; Fadiman, 1997).

\footnotetext{
Received for publication 13 Dec. 2011. Accepted for publication 8 Mar. 2012.

This paper was part of the workshop “Asia's Indigenous Horticultural Crops" held 26 July 2009 at the ASHS Conference, St. Louis, MO, and sponsored by the Working Group of Asian Horticulture (WGAH).

${ }^{1}$ To whom reprint requests should be addressed; e-mail rhmolinar@ucdavis.edu.
}

The demand for Asian vegetables in cities across the United States is increasing, making for a more lucrative market for farmers growing these crops (Miles, 2001). This increase is the result of several factors, including increasing diversity, an increase in the popularity of Asian vegetables, an emphasis on more nutritious foods, and better accessibility to recipes and uses for this group of vegetables. In one survey in the Midwest (Walters, 2008), more than $80 \%$ of the respondents ate less than $5 \mathrm{lb}$ of Asian vegetables and less than once a month. However, there was strong interest in learning more about how to eat them and 38\% said they would try them if provided recipes for their preparation. This was a predominantly non-Asian group surveyed. In Fresno, we are working with the Cooperative Extension Expanded Food and Nutrition Education Program (EFNEP) to develop Asian recipes with nutritional information and providing these to farmers selling at farmers markets, restaurants, stores, and other direct marketing avenues. We see an increased interest on the part of consumers with this information.

\section{WHAT IS IN A NAME?}

Crop common names (and spellings) vary widely depending on the ethnic group and area (University, 1998; University, 1994; Kays, 2011). Sinqua (Luffa acutangula), for example, is also called sing gua, see gwa, see kwa, shinqua, si gua, chinese okra, angled luffa, vegetable sponge, and loofah. Donqua (Benincasa hispida) is also called dongua, winter melon, and doongua (see Table 3).

\section{CUCURBITACEAE}

Bittermelon, winter melon, sinqua, opo, snake gourd, moqua. All cucurbits listed here are warm-season vegetables planted in the spring and, with the exception of winter melon, are trellised so that fruits are straighter (less curved). Most are planted on raised beds on 72-inch centers and a middle bed for walking on. All of the listed cucurbits are susceptible to nematodes, aphids, leafhoppers, several viruses, and spider mites. A lepidopterous insect feeds on the exterior causing cosmetic damage on the fruits. Although bittermelon is attacked by nematodes, it is relatively insect-free from all of the other pests mentioned.
Bittermelon (Mormodica charantia) is a native of India. It is approximately the size of a zucchini but warty. The only pests found attacking the plant in the Central Valley are parasitic root-knot nematodes. The fruits are eaten while still green and before there is any color change. Bright orange fruits are saved for seed. Bitterness (quinine content) increases with age of the fruit. Several varieties are available, which can range from 3 to 4 inches in length to almost 12 inches. Salt is used to reduce the bitterness in bittermelon. It is sliced lengthwise and stuffed with pork or seafood and top with oyster sauce or cut in half into 1/4-inch chunks and added to meat/ vegetable stir-fries. The young leaves and tips can also be steamed or stir-fried.

Opo (Lagenaria siceraria), also called bottle gourd, has large white flowers and originated in either Mexico or Egypt. Fruits are very smooth, hairless, and normally harvested when 10 to 12 inches long. This squash is the equivalent of the Italian cucuzza. It is commonly used in soups and stir-fries. The taste is mild.

Smooth luffa (Luffa cylindrica) or dishrag gourd (loofah) originated in India and was later taken to China. Most of the luffa grown in the Central Valley is for the young squashlike fruits. Luffa is sliced into 1 -inch pieces and stir-fried with shrimp in a tempura batter and cooked in oyster sauce or simply stir-fried in butter by itself or with other vegetables. Be careful not to overcook because it will become mushy. Left to mature on the plant, the squash will produce the familiar "luffa sponge" found in stores and used as a dishrag or great back scrubber (hence the name). Soak the light brown mature gourd in $10 \%$ bleach for $24 \mathrm{~h}$, then peel off the skin and allow to dry.

Angled luffa (Luffa actuangula) is similar to the smooth luffa except that it is somewhat more susceptible to spider mite attack. It also goes by the name sinqua. The quality of this squash as a sponge gourd is not as desirable; however, in stir-fries and other foods, it excels and does not become mushy as readily as smooth luffa. It is sweeter and has a better flavor than zucchini. Angled luffa should be peeled, because the ridges are fairly hard. Most plantings will have both types of luffa for the varied tastes of consumers, but the popularity of angled luffa predominates.

Snake gourd (Trichosanthes anguina) originated in Malaysia and is a vegetable squash with beautiful frilly white blossoms 
Sometimes a small stone is suspended from its tip to keep it growing straight and long; otherwise, it twists and curves like a snake. The genus Trichosanthes is Greek meaning "hair flower," which describes the fragrant and delicately fringed white corolla (petals). The young fruits are cut into pieces and boiled. As the fruit ages, it becomes bitter. Like many other bitter fruits, the bitterness is considered a beneficial tonic in traditional Chinese medicine.

Hairy melon/fuzzy gourd (Benincasa hispida var. chiehqua) is similar to the chinese winter melon, both originating in China. Most often called moqua, this squash is eaten in the immature stage, as is opo/sinqua, and before it has developed the white wax bloom on the skin. As the name implies, it is quite

Table 1. Following are examples of the diversity of Asian crops grown in Fresno County in 2008.

\begin{tabular}{|c|c|c|c|}
\hline $\begin{array}{l}\text { Chinese long } \\
\text { beans }\end{array}$ & 142 acres & Gai choy & 94 acres \\
\hline Bittermelon & 131 & Moqua & 45 \\
\hline Bok choy & 196 & Opo & 58 \\
\hline Napa cabbage & 168 & Sinqua & 51 \\
\hline Daikon & 165 & Sugar pea & 105 \\
\hline Gailon & 322 & Sugar pea leaf & 50 \\
\hline Lemon grass & 95 & Taro & 44 \\
\hline Donqua & 14 & Yam leaves & 22 \\
\hline
\end{tabular}

Table 2. California Oriental vegetables.

\begin{tabular}{lcccc}
\hline Yr & Harvested acres & $\begin{array}{c}\text { Production } \\
\text { (tons/acre) }\end{array}$ & $\begin{array}{c}\text { Price/unit } \\
\text { (dollars) }\end{array}$ & $\begin{array}{c}\text { Total value } \\
\text { (dollars) }\end{array}$ \\
\hline 2008 & 8,679 & 13.02 & 484 & $54,860,100$ \\
2007 & 10,809 & 11.45 & 565 & $69,894,000$ \\
2006 & 9,973 & 14.63 & 415 & $60,595,000$ \\
2005 & 8,829 & 15.74 & 435 & $60,421,710$ \\
\hline Soun
\end{tabular}

Source: <http://www.nass.usda.gov/Statistics_by_State/California/Publications/AgComm/Detail/index.asp>. hairy and requires peeling. It has a refreshing delicate flavor and is often included in stirfries and soups. It can be stuffed with shrimp, pork, bamboo shoots, bok choy, and onions and mixed with soy sauce, ginger, garlic, and sesame oil. Certain ethnic groups prefer the more mature stage when it develops the characteristic white waxy bloom on the skin.

Chinese winter melon (Benincasa hispida), donqua melons or wax gourd, usually weigh in excess of $30 \mathrm{lb}$ and are harvested when mature and have developed the white wax bloom on the skin. Because of its size, it is not trellised but allowed to spread over the ground. The mature melon can be stored for 3 to 4 months over the wintertime. The flavor is mild, the flesh is white, and is a main ingredient in chicken broth soup with other vegetables or stir-fried with pork. An elaborate dish is made by carving the skin like a cameo then filling the melon with other vegetables and meat. Steam until the melon flesh is soft.

\section{LEGUMINOSAE (FABACEAE)}

Chinese long beans, edible pod sugar peas, hyacinth bean. Members of this family are often trellised (sugar peas for pods and long beans) or left untrellised (hyacinth bean and sugar peas for tips or shoots).

Table 3. Common Asian vegetables in Fresno, CA.

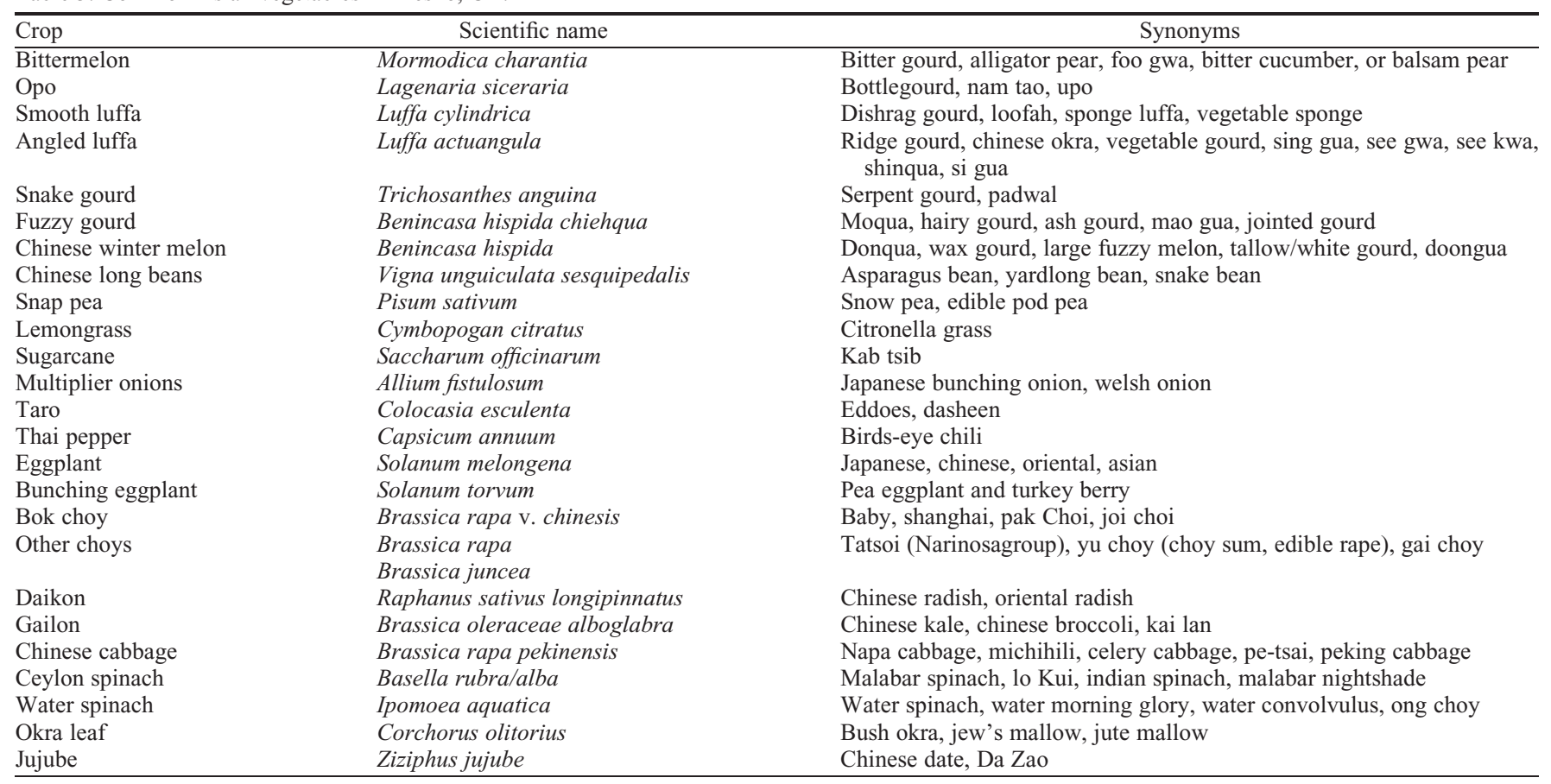


Lemongrass (Cymbopogan citratus) is in the grass family (Poaceae) and probably originated in either Malaysia or India. It is a perennial grass propagated vegetatively from stems. Another species (flexuosus) can be propagated from either seed or from stems. C. citratus is usually planted in March, and the earliest it can be harvested is October, although it can be left growing until the market price increases. In the Central Valley, five to seven rows at a time are covered with clear plastic to protect the plants from temperatures below $28{ }^{\circ} \mathrm{F}$, which can kill the aboveground portion. Below this temperature, the plastic may not help. The only known pests attacking the leaves are a fungal rust and the sugarcane aphid. Stems are chopped or pressed and add a lemony flavor to many dishes. Leaves and/or stems can be used to make a hot/cold tea drink. The plant also makes a beautiful ornamental.

Sugarcane (Saccharum officinarum) is another member of the grass family (poaceae) that originated in Asia. Small plantings totaling almost 24 acres are found in Fresno County for local consumption. Asians and Hispanics are the primary consumers. This plant is, of course, where we get our cane sugar, but the primary use here is for the peeled stalks that are chewed for their sugary juice. It is often sold at farmers markets and special occasions such as the Hmong New Year celebration.

Multiplier onions (Allium fistulosum) are a member of the Alliaceae family from China. This species will cross-pollinate with the common onion. It is a perennial, although it is usually harvested the same year. It is susceptible to downy mildew fungus like the other onions. Plants multiply by tillers from the mother plant. Multiplier onions are used in much the same way as the common green bunching onion, for flavorings and stir-fry.

Taro (Colocasia esculenta) is a member of the Araceae family from Asia. It is grown primarily for the corm or swollen stem base during the summer months. The only pest observed was the aphid. The stem, corm, and leaves must be cooked because they contain oxalates that can be very irritating to the skin and throat. There are some varieties available very low in oxalates. Two main types of taro are "common taro or Dasheen" that produces one large corm encircled with rings and "Japanese taro or eddoes" (var. antiquorium) that produces numerous smaller corms and requires a more temperate climate. The crop is a warm-season vegetable. Taro is the main ingredient in poi. It has a starchy, sweet flavor similar to a potato but is nutty like a chestnut. The texture gets more doughy as you cook it. It is used like a potato.

\section{SOLANACEAE}

Eggplants (many kinds), thai pepper. All members of this family are warm-season vegetables.

Thai pepper (Capsicum annuum) is very hot (hotter than the jalapeño and serrano), and the heat does not decrease with cooking.
This particular pepper probably originated in Southeast Asia. Caterpillars, spider mites, aphids, viruses, and phytophthora root rot are all problems found in Fresno County. Capsaicin in the pepper is responsible for the fiery heat and can burn the skin for up to $12 \mathrm{~h}$. Wear gloves when slicing the peppers and take care not to rub your eyes. Milk, cottage cheese, yogurt, or starchy foods help take away some of the heat in your mouth, definitely not beer or water. Chopped peppers fried lightly in oil for a sauce are used over any meat, fish, in noodle dishes and soups.

Oriental eggplants (Solanum melongena), which include japanese, chinese, thai, hmong, and many others, originated from the Indian subcontinent. The typical eggplant usually seen in the store is the globe-shaped American. Many of the other types are better tasting, including the chinese, italian, thai, and japanese. Other Asian types include hmong, bitter, and bunching. Pest problems include hornworms, armyworms, spider mites, lygus, aphids, and thrips. Eggplant stems and caps are cut off, halved lengthwise, brushed lightly with oil, and grilled until tender. It combines well with other vegetables in sautés and casseroles. For kabobs, they are cut into chunks and put on skewers. Eggplant chunks can be dipped in a tempura batter (flour, sugar, salt, egg, and water) and deep-fried. Eat with a shrimp cocktail sauce for a great treat.

\section{BUNCHING EGGPLANT (SOLANUM TORVUM)}

This bitter-tasting eggplant can grow 12 to $16 \mathrm{ft}$ in height and produces clusters of small 1/2-inch-diameter berries (Florida Exotic, 1998). Fruits are eaten mixed in various dishes when green. The green berries turn yellow when ripe. Plants are stout and branches are armed with large spines. The same pests that attack common eggplant varieties also attack this plant. The plant reproduces from seed as well as underground suckers and can become a weed. It is a federally listed noxious weed and was probably brought to California by Laotian refugees as seeds. It does not present a real significant problem as of yet.

\section{CRUCIFERAE}

(Mustard) bok choy, daikon, gailon, chinese cabbage. Members of this group are coolseason vegetables.

Bok choy and other choys (Brassica rapa var. chinesis) originated from China and are non-heading or loose-heading types of cabbage. Bok choy (pak choi), choy sum (var. purpurea), yu choy (similar to bok choy except it is more delicate and sweeter), gai choy (B. juncea), and tai cai (B. chinesis) are all closely related to the bok choys. Bok choy has green leaves and white midribs. Baby bok choy (Shanghai) has green midribs and leaf bases. All are used in stir-fried dishes with meat and other vegetables. The stem and leaves are also used in soups. They are also good raw in salads.
Daikon (Raphanus sativus var. longipinnatus) is also called chinese radish and is related to the common radish, originating from the Mediterranean. Alternaria leaf blight, aphids, false chinch bugs, and turnip mosaic are the main problems on the leaves, and soil wireworms can feed on the root below ground. The main planting times are spring and fall, but some varieties less prone to bolt can be planted almost year-round. Bolting (premature seed stalk) can be a problem with other varieties. Lo bok is a separate variety that may have some green coloration. There are many claimed medicinal uses in the literature for this crop. Daikon can be grated or sliced and added to various cooked dishes, fresh salads, or stir-fry with onions and shrimp (6 to $8 \mathrm{~min}$ ). The young leaves are also good when steamed and served with a little butter. Daikon seeds are slightly peppery and great in a tossed salad.

Gailon (Brassica oleracea var. alboglabra) or chinese broccoli very closely resembles the more familiar broccoli but with much smaller stems and florets. It may have origins in southern Europe. The seeds are planted for a spring crop or fall crop. Main problems are aphids, armyworms, and the cabbage butterfly. Pick just before the flowers open for best quality. The stems are more tender and sweeter than broccoli. Stir-fry the 2-inch pieces of gailon for $1 \mathrm{~min}$, then cover with water and cook covered for 2 more min. Stir oyster sauce into a pan with heated oil and water, then spoon over the broccoli and eat. Instead of oyster sauce, use minced garlic and chicken broth and a little soy sauce. It is also good in stir-fries with beef, pork, chicken, and with noodles.

Chinese cabbage (Brassica rapa var. pekinensis) is native to China and is also known as Napa cabbage. The heads are fairly dense, although not as hard as regular cabbage. There may be of two types - 'Michili', which are tall and upright, and 'Napa', which are more round or barrel-shaped. The leaves are thinner than cabbage. Pest problems include cabbageworm, loopers, armyworms, aphids, and flea beetles. The flavor is more delicate than cabbage. It is one of the last ingredients to add to a stir-fry dish. It is also added raw to salads. It is planted for fall and spring crops.

\section{MISCELLANEOUS FAMILIES}

Basellaceae. Ceylon spinach (Basella rubra and/or alba) is also known as malabar spinach with origins to India. It is a climbing tender perennial. There are two types: a red stem and a white stem. The plant is a native of the East Indies. The red is slightly more productive than the white in the Virgin Islands. Neither seems to be bothered by any pests. It can be trained on a trellis or planted on the flat and allowed to sprawl. It is grown as a warm-season annual. The succulent young and mature leaves and stems are eaten, usually mixed with other vegetables in a soup or stew. The white species retains its color, but the red loses much of its color during cooking and is 
not as attractive. The flavor is very mild and almost tasteless.

Convolvulaceae. Water spinach (Ipomoea aquatica) is a semiaquatic tender perennial from east India that roots very easily at stem nodes. The flowers are usually white and stems are hollow (to help distinguish it from a yam leaf, harvested for its stem tips). Ipomoea aquatica is a federal noxious weed in the United States. The USDA Animal and Plant Health Inspection Service (APHIS) prohibits the importation and interstate movement of this species, except under a USDA special noxious weed permit. Water spinach is on the federal noxious weed list because it becomes an established weed in fresh waterways in certain climates (Florida) where there is not a hard freeze to kill the plants. Planting can be direct seeding or from pieces of the stem. Water spinach is grown outdoors usually in hoop houses and is sensitive to frosts. Water spinach can be eaten raw or cooked. It can be stir-fried with beef, chicken, pork, or seafood. It has a milky white sap on the cut part of the stem.

Tillaceae. Okra leaf (Corchorus olitorius) is also called bush okra, jew's mallow, or jute mallow and is a popular fiber crop in West Africa, Malaysia, Egypt, the Philippines, and Central America. Plants with small yellow flowers borne in the leaf axils can grow to more than $5 \mathrm{ft}$ tall. It is an upright, slightly woody herb with serrated leaves. The plant is warm season. The edible shoot tips are cooked in stews and have a mucilaginous consistency similar to okra (unrelated). In West Africa the leaves and tips are stored dry, and in India, the shoots are cooked with rice.

Rhamnaceae (Buckthorn). Jujube (Ziziphus jujube) is also commonly called "chinese date." Jujube was first introduced into the United States in 1837 in North Carolina. Its origin is probably from Syria. The plant is a deciduous tree that can grow to $30 \mathrm{ft}$. Most of the varieties have thorns on the branches. Commonly planted varieties include Li, Lang, and Sherwood. Trees can withstand temperatures as low as minus $20^{\circ} \mathrm{F}$. The only pest observed is an eriophyid mite. The fruit can be eaten either fresh or dried. The fresh green/brown fruits taste similar to a dry-tasting apple. The dry fruit resembles a date and can be used as a date substitute. Yields can be so high that branches break from the weight of the fruit. In high heat, the fruits are susceptible to sunburn. It has been reported as presenting a weedy problem in some parts of the United States; however, in California, there have not been any problems with the tree.

\section{Literature Cited}

California Agriculture Statistics Service. 2003. California agriculture statistics 2003. Sacramento, CA.

California Farm Bureau Federation. 2003. Facts about California agriculture. Sacramento, CA.
Fadiman, A. 1997. The spirit catches you and you fall down. Noonday Press, New York, NY.

Florida Exotic Pest Council. 1998. Solanum torvum Sw. <http://www.fleppc.org/ID_book/solanum $\% 20$ torvum.pdf $>$.

Great Valley Center. 1999. Assessing the region via indicators: Productivity and diversity of California agriculture. $<$ http://www.greatvalley. org/indicators/econo/ag_div.aspx>.

Ilic, P. 1992. SE Asian farmers in Fresno CountyStatus report. Survey unpublished data.

Kays, S.J. 2011. Cultivated vegetables of the world: A multilingual onomasticon. Wageningen Academic Publishers, The Netherlands.

Miles, C. and D. Alleman. 2001. Promoting and marketing Asian crops. HortTechnology 11: 517-521.

NPR. 2002. California's Central Valley. 11-14 Nov. $<$ http://www.npr.org/programs/atc/features/2002/ nov/central_valley/>.

Umbach, K. 1997. A statistical tour of California's great valley. $<$ http://www.library.ca.gov/CRB97/ 09>.

University of California. 1994. Small farm handbook. Small Farm Program. Division of Agriculture and Natural Resources. Publ. SFP001.

University of California. 1998. Specialty and minor crops handbook. Small Farm Program. Division of Agriculture and Natural Resources. Publ. 3346.

USDA-NASS. 2002. Census of Agriculture. <http:// www.nass.usda.gov/census>.

Walters, S. Alan, K. Range, B. Taylor, and W. Moon. 2008. Consumer attitudes for Asian vegetables in direct markets. HortTechnology 18:500 505 . 